\title{
Histamine in canned and smoked fishery products sold in Serbia
}

\author{
Stefan Simunovic ${ }^{l *}$, Sasa Jankovic ${ }^{l}$, Tatjana Baltic ${ }^{l}$, Dragica Nikolic ${ }^{l}$, Jasna Djinovic-Stojanovic ${ }^{l}$, \\ Mirjana Lukic ${ }^{l}$, Nenad Parunovic ${ }^{l}$
}

A b s tr a c t: An increase in seafood-related illnesses as a consequence of an increase in seafood consumption has been documented recently. The United States Food and Drug Administration (FDA) has identified histamine as the major chemical hazard of seafood. The aim of this study was to determine histamine levels in 227 production lots (2043 subsamples) of canned tuna, canned sardines, canned mackerel and smoked salmon obtained from Serbian retail stores in 2018. Levels of histamine were determined using high performance liquid chromatography tandem mass-spectrometry. In addition, we compared histamine levels found in analysed products with levels established by the European Commission (EC) and FDA. Mean levels of histamine in compliant lots, according to EC Regulation 2073/2005, were 9.21, 3.16, 3.34 and $5.22 \mathrm{mg} / \mathrm{kg}$ in canned tuna, canned sardines, canned mackerel and smoked salmon, respectively. The highest histamine levels were found in canned tuna and canned mackerel, $1112 \mathrm{mg} / \mathrm{kg}$ and $412 \mathrm{mg} / \mathrm{kg}$, respectively. Histamine was detected in 468 (22.91\%) of all analysed subsamples. Levels above $100 \mathrm{mg} / \mathrm{kg}$, which is the maximum histamine level allowed in canned fish in the EU, were found in 38 (1.86\%) of analysed subsamples. According to EC Regulation 2073/2005, six (2.64\%) of all analysed lots were found non-compliant, while 21 (9.25\%) of analysed lots should be rejected according to the FDA limit (50 mg/kg).

Keywords: histamine, canned tuna, mackerel, sardine, food safety.

\section{Introduction}

Globally, more than 63.5 million tons of seafood is caught and eaten each year, representing a steady global increase in seafood consumption (Silva et al., 2011). Some authors have indicated the health benefits of marine fish consumption, mostly due to the role of n-3 fatty acids in alleviating cardiovascular diseases, lowering blood pressure and in preventing the development of hypertension (Narayan et $a l ., 2006)$. This is probably the reason why consumer awareness of the health benefits of incorporating fish in diets is constantly growing. However, an increase in seafood-related illnesses as a consequence of this increase in seafood consumption has been documented (Butt et al., 2004). The United States Food and Drug Administration (FDA) has identified histamine as the major chemical hazard of seafood. Recently, greater interest can be observed in the area of seafood safety, especially when it comes to histamine, both in Serbia and worldwide (Karmi, 2014; Dimitrijevic et al., 2016; Petrovic et al., 2016; Ryok Kang et al., 2018; Zhang et al., 2018).
Histamine fish poisoning (HFP), also known as scombrotoxin fish poisoning (SFP), is a foodborne chemical intoxication mostly caused by the ingestion of spoiled or bacterially contaminated scombroid fish that are characterised by high levels of the amino acid histidine in muscle tissue. Scombroid fish belong to the families Scombridae (mackerel, tuna, bonito) and Scomberesocidae (saury). High levels of histidine are also found in other fish families such as Clupeidae (sardine, herring), Coryphaenidae (mahi-mahi), Gempylidae (escolar), Istiophoridae (marlin, sailfish) and Carangidae (amberjack or yellowtail), which were implicated in histamine intoxication outbreaks (Schulze et al., 1979; Muller et al., 1992; Feldman et al., 2005; Chen et al., 2010; Chen et al., 2011).

Histamine is a biogenic amine with a heterocyclic structure and it can be found in foods such as meat, cheese, wine and other fermented foods as well as in fish. Histamine is derived from the decarboxylation of histidine by the enzyme histidine decarboxylase (HDC). HDC is produced by bacteria which are part of natural microbiota of fish.

${ }^{1}$ Institute of Meat Hygiene and Technology, Kacanskog 13, 11000 Belgrade, Serbia.

*Corresponding author: Stefan Simunovic: stefan.simunovic@inmes.rs 
According to the European Food Safety Authority (EFSA, 2011), bacteria species that are the strongest histamine producers are Hafnia alvei, Morganella morganii, Klebsiella pneumonia, Morganella psychrotolerans, Photobacterium phosphoreum and Photobacterium psychrotolerans. Some bacteria that belong to the family Enterobacteriaceae, such as Enterobacter asburiae, Enterobacter cloacae, Enterobacter hormaechei, Citrobacter amalonaticus and Cronobacter sakazakii, are also capable of producing histamine (Zhang et al., 2018). Although the main means to prevent the occurrence of histamine is maintenance of low temperatures during fish processing, Emborg et al. (2005) found that psychrotolerant bacteria are capable of producing toxic concentrations of histamine in tuna at $2^{\circ} \mathrm{C}$.

In contrast to bacterial pathogens, histamine is heat stable, and it cannot be eliminated or reduced by heat treatment; therefore, maintenance of the cold chain along all stages of fish processing is essential. Heating processes can only be used to eliminate histamine-producing bacteria and their HDC enzymes from the product (FAO/WHO, 2013). However, some authors reported different methods that can degrade histamine and other biogenic amines such as gamma irradiation and application of diamine oxidase bacteria (Dapkevicius et al., 2000; Kim et al., 2004).

The symptoms associated with HFP are similar to those of an allergic reaction and include hypertension, flushing, headache, urticaria, nausea, vomiting, diarrhoea and abdominal cramps (Maintz and Novak, 2007). The presence of certain histamine potentiators in fish, such as cadaverine and putrescine, could decrease the dose of histamine needed to provoke an adverse reaction in humans (FAO/ WHO, 2013). The symptoms typically occur rapidly, from 5 mins to $2 \mathrm{~h}$ after ingestion, with a usual duration of $8 \mathrm{~h}$. Many incidents go unreported because of the mildness of the disease, lack of mandatory reporting and misdiagnosis, because symptoms can be confused with Salmonella infection and food allergy (Silva et al., 2011).

According to reports from the Rapid Alert System for Food and Feed, in 2018, 29 products were reported in which histamine levels were above the European Commission (EC) regulated maximum limit (European Commission, 2015). Well designed good hygienic practice (GHP), good manufacturing practice (GMP) and hazard analysis (and) critical control point (HACCP) plans are essential steps in preventing histamine formation above the safety limits. Rapid chilling of the fish soon as possible after harvesting and maintenance of the cold chain through all stages of fish processing are the most important factors in preventing histamine production above the safety limit. EFSA indicate that the food categories showing the highest mean histamine levels are dried anchovies, fish sauce, fermented vegetables, cheese, other fish and fish products and fermented sausages (EFSA, 2011). According to Zhai et al. (2012), the main fish species used in canned products are scombroid fish (Spanish mackerel, tuna) and non-scombroid fish (anchovy, sardine) that are commonly associated with HFP. Sensory evaluation of the fish is not sufficient to detect the absence or presence of histamine, and it cannot be taken as final assurance of low histamine level; therefore chemical testing is required.

The aim of this study was to provide information regarding the presence of histamine in canned tuna, canned sardines, canned mackerel and smoked salmon present in Serbian retail stores in 2018 and to evaluate the safety of these products in regard to histamine levels established by the European Commission (European Commission, 2015) and FDA (FDA, 1995).

\section{Materials and Methods}

\section{Standards and reagents}

Histamine standard was obtained from Sigma-Aldrich (St. Louis, MO, USA). Acetonitrile and water of HPLC grade were from Sigma-Aldrich (St. Louis, MO, USA). Ammonium acetate and formic acid were purchased from Merck (Darmstadt, Germany). Trichloroacetic acid (TCA) was from Fisher Chemical (Hampton, NH, USA).

\section{Fish samples and extraction}

A total of 227 lots of canned fish and smoked salmon samples were analysed. Every lot consisted of 9 subsamples, making a total of 2043 subsamples. All subsamples were collected from Serbian retail stores during 2018 and they were all imported from other countries. The fish samples analysed included canned tuna (91), canned sardines (54), canned mackerel (13) and smoked salmon (69). All samples were homogenised using a bowl chopper (Blixer 2, Robot Coupe, France). A $1 \mathrm{~g}$ amount of each sample was transferred into a polypropylene tube, followed by addition of $10 \mathrm{~mL}$ of $6 \%(\mathrm{w} / \mathrm{v})$ TCA. The mixture was vortexed for $20 \mathrm{~min}$ and then centrifuged at $4000 \mathrm{rpm}$ for $5 \mathrm{~min}$. 
The supernatants were filtered through $0.45 \mu \mathrm{m}$ pore-size nylon syringe filters (Amtast, Lakeland, FL, USA) into HPLC vials.

\section{$L C-M S / M S$}

The quantification of histamine was carried out using a Shimadzu (Shimadzu Corporation, Kyoto, Japan) system consisting of two LC-30AD UPLC pumps connected in binary gradient mode, DGU20A degassing unit, SIL-30AC autosampler, CTO20AC column oven, CBM-20A system controller and LCMS 8040 triple quadrupole MS detector. Heat block, interface and desolvation line temperatures were $400^{\circ} \mathrm{C}, 350^{\circ} \mathrm{C}$ and $250^{\circ} \mathrm{C}$ respectively. Instrument control, data acquisition and evaluation were accomplished with the LabSolutions software (Shimadzu Corporation, Kyoto, Japan). Three transitions of histamine were monitored $(\mathrm{m} / \mathrm{z} \quad 112>54$, $\mathrm{m} / \mathrm{z} \quad 112>68$ and $112>95$ ). Chromatographic separation of histamine was carried out on a Kinetex ${ }^{\circledR}$ (Phenomenex, Torrance, CA, USA) column $(100 \times 2.1 \mathrm{~mm}, 2 \mu \mathrm{m})$ at $50^{\circ} \mathrm{C}$ with an isocratic flow rate of $0.35 \mathrm{~mL} / \mathrm{min}$. The mobile phase consisted of $10 \mathrm{mM}$ ammonium acetate in water (mobile phase A) and $0.1 \%$ formic acid in acetonitrile (mobile phase $B$ ) in the ratio $A: B=20: 80$.

\section{Method validation}

The analytical method was validated according to Thompson et al., (2002). The experimentally determined limit of detection (LoD) was $2 \mathrm{mg} / \mathrm{kg}$, while the limit of quantification (LoQ) was $5 \mathrm{mg} /$ $\mathrm{kg}$. Linearity was acceptable within the concentration range of 5-250 $\mathrm{mg} / \mathrm{kg}$, and the relative standard deviation of reproducibility was between $1.69 \%$ (at $250 \mathrm{mg} / \mathrm{kg}$ ) and $13.93 \%$ (at $5 \mathrm{mg} / \mathrm{kg}$ ). Measurement uncertainty of the method was calculated according to the NORDTEST concept (Magnusson et al., 2012 ) and was $4.42 \%$ at $100 \mathrm{mg} / \mathrm{kg}$.

\section{Statistical analysis}

The percentage of samples containing histamine among groups based on different histamine level, mean histamine levels and standard deviation were determined using SPSS package (SPSS 23.0, Chicago, IL, USA). To distinguish statistical differences between the data, T-tests were performed with statistical significance being set at $\mathrm{p}<0.001$, using the above-mentioned software package.

\section{Results and Discussion}

Histamine levels in 2043 subsamples of canned tuna, canned sardines, canned mackerel and smoked salmon are presented in Table 1. Large variations in histamine level in different cans with same lot number were previously reported by Petrovic et al. (2016) while investigating a histamine intoxication outbreak in Serbia. When considering product safety, it is essential to present results of all analysed subsamples, rather then mean levels. According to EFSA, fish containing less than $50 \mathrm{mg} / \mathrm{kg}$ of histamine seems to be safe for human consumption, whereas concentrations between 50 and $200 \mathrm{mg} / \mathrm{kg}$ may cause adverse health effects and levels above $200 \mathrm{mg} / \mathrm{kg}$ histamine are reported to cause toxic effects in humans (EFSA, 2011). Based on these limits, $78(3.82 \%)$ of 2043 analysed subsamples could have caused adverse health effects when eaten. In the EU, for simple fish products, the critical concentration of histamine is $100 \mathrm{mg} / \mathrm{kg}$, and for the enzyme matured products, the critical histamine concentration is $200 \mathrm{mg} / \mathrm{kg}$. One sample consists of nine units, two of which can contain levels between 100 and $200 \mathrm{mg} / \mathrm{kg}$, i.e. $200-400 \mathrm{mg} / \mathrm{kg}$ for enzyme-treated products (Commission Regulation (EC) No. 2073/2005). In Serbia, the regulation that governs histamine in fish (Official Gazette RS, 2010) is in accordance with EC Regulation 2073/2005. In $78(3.82 \%)$ of all our analysed subsamples, histamine levels were above the FDA (1995) action level $(50 \mathrm{mg} / \mathrm{kg})$, making a total of 21 rejected lots, while 6 lots were non-compliant according to EC Regulation 2073/2005. Figure 1 shows a chromatogram of three transitional products of histamine at $50 \mathrm{mg} / \mathrm{kg}$ in one fish sample.

Histamine levels above $200 \mathrm{mg} / \mathrm{kg}$, which is the upper limit in the EU, were found in 12 subsamples of canned tuna and in 8 subsamples of canned mackerel. Suyama and Yoshizawa (1973) investigated the free amino acid composition of some fish species and found histidine levels above $12000 \mathrm{mg} /$ $\mathrm{kg}$ and $7400 \mathrm{mg} / \mathrm{kg}$ in Thunnus albacares (yellowfin) and Thunnus obesus (big-eye tuna), respectively. High levels of histidine $(8020 \mathrm{mg} / \mathrm{kg})$ were also found in Scomber japonicus (mackerel) (Hibiki and Simidu, 1959). According to the FAO, the highest histidine level reported for Sardina pilchardus (sardines) was $2888 \mathrm{mg} / \mathrm{kg}$, which is much lower than those found in tuna and mackerel (FAO/ $W H O, 2013)$. In the current study, the mean histamine level found in canned sardines was lower than those of canned tuna and canned mackerel, which 
Table 1. Histamine content in all subsamples $(\mathrm{n}=2043)$ analysed in this study and number of non-compliant lots according to EC and FDA regulations

\section{No. (\%) of subsamples with a histamine content $(\mathrm{mg} / \mathrm{kg})$ of:}

\begin{tabular}{|c|c|c|c|c|c|c|c|c|c|}
\hline Product & $\begin{array}{l}\text { No. of sub- } \\
\text { samples } \\
\text { (lots) }\end{array}$ & $<\mathrm{LoQ}^{\mathrm{a}}$ & 5-50 & 50-100 & $100-150$ & $150-200$ & $>200^{\mathrm{b}}$ & $\begin{array}{l}\text { No. }(\%) \text { of } \\
\text { non-com- } \\
\text { pliant lots } \\
(E C)^{\mathrm{c}}\end{array}$ & $\begin{array}{l}\text { No. }(\%) \text { of } \\
\text { non-com- } \\
\text { pliant lots } \\
(\text { FDA })^{d}\end{array}$ \\
\hline $\begin{array}{l}\text { Canned } \\
\text { tuna }\end{array}$ & 819 (91) & 480 (58.91) & $286(34.92)$ & $27(3.30)$ & $3(0.37)$ & $11(1.34)$ & $12(1.46)$ & $4(4.40)$ & $13(14.29)$ \\
\hline $\begin{array}{l}\text { Canned } \\
\text { sardines }\end{array}$ & $486(54)$ & $440(90.53)$ & $44(9.05)$ & $2(0.41)$ & 0 & 0 & 0 & 0 & $2(3.70)$ \\
\hline $\begin{array}{l}\text { Canned } \\
\text { mackerel }\end{array}$ & $117(13)$ & $92(78.63)$ & 14 (11.97) & $2(1.71)$ & $1(0.85)$ & 0 & $8(6.84)$ & $2(15.38)$ & $2(15.38)$ \\
\hline $\begin{array}{l}\text { Smoked } \\
\text { salmon }\end{array}$ & $621(69)$ & $563(90.66)$ & $45(7.25)$ & $10(1.61)$ & $2(0.32)$ & $1(0.16)$ & 0 & 0 & $4(5.80)$ \\
\hline
\end{tabular}

a Subsamples in which histamine levels were below limit of quantification (LoQ) ( $5 \mathrm{mg} / \mathrm{kg}$ ).

${ }^{\mathrm{b}}$ Subsamples in which histamine levels were above $200 \mathrm{mg} / \mathrm{kg}$.

${ }^{c}$ Non-compliant lots according to EC Regulations

d Non-compliant lots according to FDA Regulations

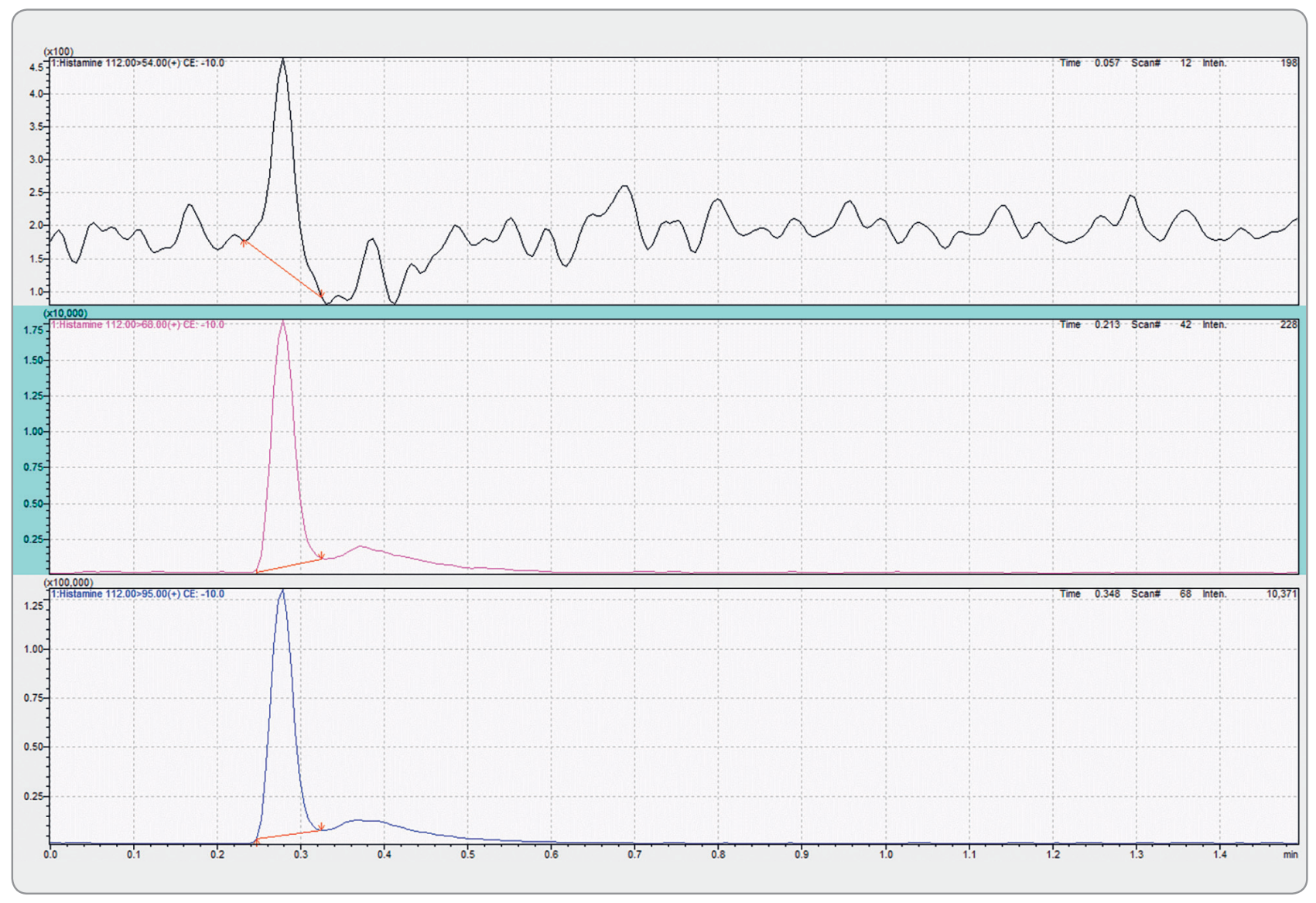

Figure 1. MRM chromatograms of histamine at a concentration of $50 \mathrm{mg} / \mathrm{kg}$. Chromatograms depict transitional products $112>54 \mathrm{Da}, 112>68 \mathrm{Da}, 112>95$. 
indicates the strong relationship between histidine level in muscle tissue and high histamine content in the product.

The quality of the analytical process was confirmed by the analysis of the certified reference material T27229QC (Fera Science Ltd., York, United Kingdom) within each batch of analysed samples. The certified histamine content was $45 \mathrm{mg} / \mathrm{kg}$. Obtained histamine contents for this certified product were within $\pm 15 \%$ of the certified content. Chromatograms of three transitional products of histamine in the certified reference material is presented in Figure 2.

According to Commission Regulation 2073/ 2005, all subsamples of our canned sardines and smoked salmon showed histamine levels below the safe level of $100 \mathrm{mg} / \mathrm{kg}$, with the exception of three subsamples of smoked salmon from three different production lots. Histamine levels below the laboratory LoQ were found in 1601 (76.68\%) of all analysed samples, while histamine levels in $58.91 \%$ samples of canned tuna were below the LoQ. This percentage was slightly higher than that reported by Dimitrijevic et al. (2016) who found histamine levels in $50.37 \%$ of canned tuna samples to be below the LoQ. In a similar study conducted in Serbia, histamine levels in canned tuna samples were found to be below the LoQ in $54.40 \%$, between 10 and 50 $\mathrm{mg} / \mathrm{kg}$ in $34.40 \%$ and between 50 and $100 \mathrm{mg} / \mathrm{kg}$ in $4 \%$ of analysed lots (Petrovic et al., 2016), which is in accordance with results found in this study. Levels above $100 \mathrm{mg} / \mathrm{kg}$ were found in 25 (3.04\%) of our canned tuna samples. In contrast to this, Karmi (2014) found histamine levels in $33.3 \%$ of canned tuna samples were above $100 \mathrm{mg} / \mathrm{kg}$. High histamine levels in these canned tuna indicate poor temperature treatment and a lack of hygiene during processing. Canned tuna is often used in the preparation of different types of salads, where recontamination and time-temperature abuse can lead to formation of histamine in levels that can cause HFP (Predy et al., 2003; McCarthy et al., 2015).

The highest histamine level found in our canned sardines was $78 \mathrm{mg} / \mathrm{kg}$, which is in accordance with the results reported by Karmi (2014) and Pacheco-Aguilar et al. (1998), who found maximum levels of 62 and $70.3 \mathrm{mg} / \mathrm{kg}$, respectively. These results differ from data presented by Petrovic et al. (2016), who reported a maximum histamine level of $19.1 \mathrm{mg} / \mathrm{kg}$ in canned sardines.

Kim et al. (2002) investigated histamine production by Morganella morganii in four different fish families at $37,25,15$ and $4^{\circ} \mathrm{C}$ for $36,36,60$ and
$14 \mathrm{~h}$, respectively. They found levels below $50 \mathrm{mg} /$ $\mathrm{kg}$ in all salmon samples, while levels in macker$\mathrm{el}$, albacore and mahi-mahi exceeded $50 \mathrm{mg} / \mathrm{kg}$ in a few hours at different temperatures, with the exception of fish held at $4^{\circ} \mathrm{C}$. Similar result were reported by Crapo and Himelbloom (1999), who found no histamine production in pink salmon during 14 days of storage at $10^{\circ} \mathrm{C}$. These results are comparable with results found in present study, in which we found $97.91 \%$ of smoked salmon samples had histamine levels below $50 \mathrm{mg} / \mathrm{kg}$, while $90.66 \%$ were below the LoQ. This is attributed to low histidine contents in muscle tissue of salmon and probably due to good hygiene and low storage temperatures during fish processing. Although salmon is not histidine rich, Bartholomew et al. (1987) reported 12 incidents of salmon being involved in HFP from 1976 to 1986 in Britain.

Mean histamine contents were calculated for all analysed subsamples of each product and for all subsamples of compliant production lots according to the Commission Regulation 2073/2005 in order to avoid outliers. Histamine levels varied significantly $(\mathrm{p}<0.001)$ among the analysed fish products (Table 2). These results are in accordance with those reported by Yesudhason et al. (2013), who found a significant difference $(\mathrm{p}<0.05)$ between mean histamine levels in canned tuna and canned sardines. Our mean histamine level $(9.21 \mathrm{mg} / \mathrm{kg})$ in canned tuna calculated for compliant production lots was similar to those found by Er et al. (2014), lower than that reported by Tsai et al. (2005) but higher then those found by Silva et al. (2011), who reported very low levels of histamine for different canned tuna products in Brazil. In the current study, the mean histamine level in canned mackerel samples for compliant lots $(3.34 \mathrm{mg} / \mathrm{kg})$ was in accordance with that reported by Tsai et al. (2005) but much lower then that reported by Karmi (2014), who found histamine at $68 \mathrm{mg} / \mathrm{kg}$ in canned mackerel, with a maximum level of $82 \mathrm{~kg} / \mathrm{kg}$.

In several histamine intoxication outbreak studies, reported levels of histamine in leftovers of different fish and fish products ranged from 293 $\mathrm{mg} / \mathrm{kg}$ to $5200 \mathrm{mg} / \mathrm{kg}$ (Feldman et al., 2005; Tsai et al., 2005; Chen et al., 2008; Chen et al., 2010; Ryok Kang et al., 2018). Reported symptoms were flushing, headache, rash, nausea, diarrhoea, sweating, peppery taste and dizziness but no cases of death. In the current study, maximum levels of histamine found in canned tuna, canned mackerel and smoked salmon were 1112, 412 and $122 \mathrm{mg} / \mathrm{kg}$, respectively. Based on histamine intoxication studies, 
we can conclude that levels of histamine we found in tuna and mackerel could have caused HFP in healthy individuals. However, the usual portion size of canned tuna per consumer is about $130 \mathrm{~g}$, which corresponds to a total of $144.5 \mathrm{mg}$ of histamine in a portion of canned fish containing 1112 $\mathrm{mg} / \mathrm{kg}$ of histamine. The high levels of histamine we measured in these canned fish products leads to the conclusion that poor quality raw fish has been used for their production. Motil and Scrimshaw
(1979) reported that ingestion of 50,100, 150 and $180 \mathrm{mg}$ of histamine via tuna caused typical symptoms such as mild headache and flush in 1, 3, 4 and 7 of 8 healthy individuals, respectively. However, this dosage levels will not apply to individuals with a specific sensitivity to histamine and would not apply to children, particularly because they consume more food per unit body weight than adults (FAO/WHO, 2013). Storage temperature is the most important factor contributing to biogenic amine

Table 2. Histamine levels $(\mathrm{mg} / \mathrm{kg})$ for different fish products analysed in this study and levels for compliant lots according to EC Regulations (mean $\pm \mathrm{SD}$ )

\begin{tabular}{lcccccc}
\hline & Compliant lots $^{\mathbf{a}}$ & Median & Max & All analysed lots $^{\mathbf{b}}$ & Median & Max \\
\hline Canned tuna & $9.21 \pm 14.8^{\mathrm{c}}$ & 2.5 & 1112 & $21.70 \pm 89.1^{\mathrm{c}}$ & 2.5 & 169 \\
Canned sardines & $3.16 \pm 3.8^{\mathrm{d}}$ & 2.5 & 78 & $3.16 \pm 3.8^{\mathrm{d}}$ & 2.5 & 78 \\
Canned mackerel & $3.34 \pm 3.5^{\mathrm{d}}$ & 2.5 & 26 & $26.45 \pm 77.2^{\mathrm{c}}$ & 2.5 & 412 \\
Smoked salmon & $5.22 \pm 13.7^{\mathrm{e}}$ & 2.5 & 171 & $5.22 \pm 13.7^{\mathrm{e}}$ & 2.5 & 171 \\
\hline
\end{tabular}

a Subsamples of compliant lots. For levels below LoQ, the level used was $2.5 \mathrm{mg} / \mathrm{kg}$.

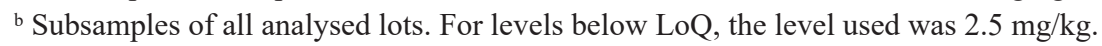

c-e Values in the same column followed by different letters are significantly different $(\mathrm{p}<0.001)$.

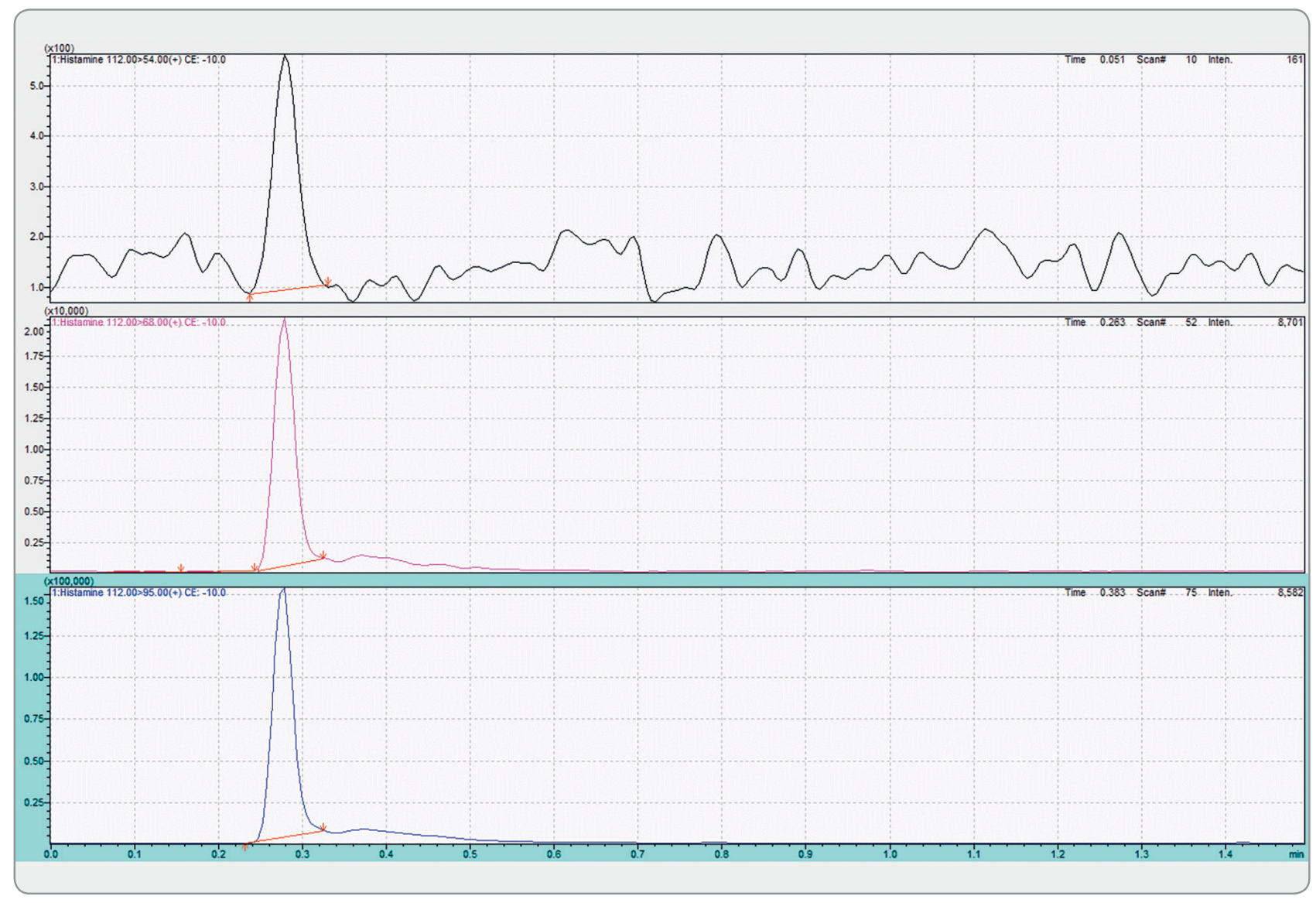

Figure 2. MRM chromatograms of histamine in certified reference material used for quality control of analytical process. Chromatograms depict transitional products $112>54 \mathrm{Da}, 112>68 \mathrm{Da}, 112>95$. 
formation, although a variety of techniques can be combined together to control the microbial growth and enzyme activity during processing and storage for better shelf life extension and food safety (Chong et al., 2011).

\section{Conclusion}

In this study, four $(4.40 \%)$ production lots of canned tuna and two (15.38\%) lots of canned mackerel were non-compliant for histamine levels according to Commission Regulation (EC) No. 2073/2005. In contrast, in $13(14.29 \%)$ lots of canned tuna and two $(15.38 \%)$ lots of canned mackerel, histamine levels were above the FDA action limit of $50 \mathrm{mg} /$ $\mathrm{kg}(F D A, 1995)$. Although the histamine content in all our canned sardines and smoked salmon samples were compliant according to EC Regulation $2073 / 2005$, two $(3.70 \%)$ production lots of canned sardines and four $(5.80 \%)$ production lots of smoked salmon would be non-compliant if we had applied the FDA action limit, due to the much stringent requirements. Canned tuna had the highest mean histamine levels, followed by smoked salmon and canned mackerel, while canned sardines contained the lowest mean histamine level. Histamine was detected in 468 (22.91\%) subsamples of all analysed fish products.

\title{
Histamin u konzerviranim i dimljenim proizvodima od ribe koji se prodaju na tržištu u Srbiji
}

\author{
Stefan Simunović, Saša Janković, Tatjana Baltić, Dragica Nikolić, Jasna Đinović-Stojanović, Mirjana Lukić, \\ Nenad Parunović
}

A p s tr a k t: Poslednjih godina primećeno je povećanje broja bolesti povezanih sa konzumacijom plodova mora kao posledica povećanja konzumacije ovih proizvoda. Uprava za hranu i lekove Sjedinjenih Američkih Država (eng. FDA) označila je histamin kao glavnu hemijsku opasnost plodova mora. Cilj rada bio je da se odredi sadržaj histamina u 227 proizvodnih lotova konzervirane tune, konzervirane sardele, konzervirane skuše i dimljenog lososa. Svi uzorci su prikupljeni iz maloprodajnih objekata u Republici Srbiji tokom 2018. godine. Za ispitivanje histamina korišćena je tečna hromatografija visokih performansi sa masenom detekcijom. Dobijene rezultate smo uporedili sa nivoima koje su uspostavili Evropska komisija i FDA. Histamin je detektovan u 468 (22.91\%) jedinica analiziranih proizvoda. U skladu sa propisom Evropske komisije 2073/2005, šest (2.64\%) ispitivanih proizvodnih lotova su ocenjeni kao nezadovoljavajući, dok su čak 21 proizvodnih lotova ocenjeni kao nezadovoljavajući u skladu sa propisom FDA.

Ključne reči: histamin, tuna u konzervi, skuša, sardela, bezbednost hrane.

Disclosure Statement: No potential conflict of interest was reported by the authors.

Acknowledgements: We thank Prof. dr. Milos B. Rajkovic from Institute of Food Technology and Biochemistry, Faculty of Agriculture for scientific advice.

\section{References}

Bartholomew, B. A., Berry, P. R., Rodhouse, J. C., Gilbert, R. J. \& Murray, C. K. (1987). Scombrotoxic fish poisoning in Britain: Features of over 250 suspected incidents from 1976 to 1986. Epidemiology and Infection, 99 (3), 775-782.

Butt, A., E Aldridge, K. \& V Sanders, C. (2004). Infections related to the ingestion of seafood Part I: Viral and bacterial infections. The Lancet Infectious Diseases, 4 (1), 201-12.

Chen, H. C., Huang, Y. R., Hsu, H. H., Lin, C. S., Chen, W. C., Lin, C. M. \& Tsai, Y. H. (2010). Determination of histamine and biogenic amines in fish cubes (Tetrapturus angustirostris) implicated in a food-borne poisoning. Food Control, 21 (1), 13-18.

Chen, H. C., Kung, H. F., Chen, W. C., Lin, W. F., Hwang, D. F., Lee, Y. C. \& Tsai, Y. H. (2008). Determination of histamine and histamine-forming bacteria in tuna dumpling implicated in a food-borne poisoning. Food Chemistry, 106 (2), 612-618.

Chen, H. C., Lee, Y. C., Hwang, D. F., Chiou, T. K. \& Tsai, Y. H. (2011). Determination of histamine in mahi-mahi fillets (Coryphaena hippurus) implicated in a foodborne poisoning. Journal of Food Safety, 31 (3), 320-325. 
Chong, C. Y., Bakar, F. A., Russly, A. R., Jamilah, B. \& Mahyudin, N. A. (2011). The effects of food processing on biogenic amines formation. International Food Research Journal, 18 (3), 867-876.

Commission Regulation (EC) No 2073/2005 of 15 November 2005 on microbiological criteria for foodstuffs. Official Journal of the European Union, L 338, 1-26.

Crapo, C. \& Himelbloom, B. (1999). Spoilage and histamine in whole pacific herring (Clupea harengus pallasi) and pink salmon (Oncorhynchus gorbuscha) fillets. Journal of Food Safety, 19 (1), 45-55.

Dapkevicius, M. L. N. E., Nout, M. J. R., Rombouts, F. M., Houben, J. H. \& Wymenga, W. (2000). Biogenic amine formation and degradation by potential fish silage starter microorganisms. International Journal of Food Microbiology, 57 (1), 107-114.

Dimitrijevic, M., Stefanovic, S., Karabasil, N., Vasilev, D., Cobanovic, N., Grkovic, N. \& Djordjevic, V. (2016). UPLC-MS/MS determination of histamine levels in canned fish collected from Belgrade retail markets. Meat Technology, 57 (1), 47-56.

EFSA. (2011). Scientific Opinion on risk based control of biogenic amine formation in fermented foods. EFSA Journal, 9 (10), 2393.

Emborg, J., Laursen, B. G. \& Dalgaard, P. (2005). Significant histamine formation in tuna (Thunnus albacares) at 2 ${ }^{\circ} \mathrm{C}$ - effect of vacuum- and modified atmosphere-packaging on psychrotolerant bacteria. International Journal of Food Microbiology, 101 (3), 263-279.

Er, B., Demirhan, B., Bas, S. Y., Yentur, G. \& Oktem, A. B. (2014). Determination of histamine levels in canned tuna fish. Bulgarian Journal of Agricultural Science, 20 (4), 834-838.

Feldman, K., B Werner, S., Cronan, S., Hernandez, M., Horvath, A. R., S Lea, C., M Au, A. \& J Vugia, D. (2005). A large outbreak of scombroid fish poisoning associated with eating escolar fish (Lepidocybium flavobrunneum). Epidemiology and Infection, 133 (1), 29-33.

FAO/WHO Food and Agriculture Organization of the United Nations/World Health Organization. (2013). Public health risks of histamine and other biogenic amines from fish and fishery products. Meeting report.

FDA Food and Drug Administration. (1995). Decomposition and histamine-raw frozen tuna and mahi-mahi; canned tuna; and related species; availability of revised compliance policy guide, Federal Registration, 60 (1), 39754-39756.

Hibiki, S. \& Simidu, W. (1959). Studies on putrefaction of aquatic Products-27 Inhibition of histamine formation in spoiling of cooked fish and histidine content in various fishes. Nippon Suisan Gakkaishi, 24 (11), 916-919.

Karmi, M. (2014). Determination of histamine and tyramine levels in canned salted fish by using HPLC. Global Veterinaria, 12 (2), 264-269.

Kim, J. H., Ahn, H. J., Jo, C., Park, H. J., Chung, Y. J. \& Byun, M. W. (2004). Radiolysis of biogenic amines in model system by gamma irradiation. Food Control, 15 (5), 405-408.

Kim, S. H., Price, R. J., Morrissey, M. T., Field, K. G., Wei, C. I. \& An, H. (2002). Histamine production by Morganella morganii in mackerel, albacore, mahi-mahi, and salmon at various storage temperatures. Journal of Food Science, 67 (4), 1522-1528.
Magnusson, B., Näykki, T., Hovind, H. \& Krysell, M. (2012). Handbook for calculation of measurement uncertainty in environmental laboratories, Nordtest Report TR 537 (version 3.1). Available from www.nordtest.info.

Maintz, L. \& Novak, N. (2007). Histamine and histamine intolerance. American Journal of Clinical Nutrition, 85 (5), 1185-1196.

McCarthy, S., Bjornsdottir-Butler, K. \& Benner, R., Jr. (2015). Storage time and temperature effects on histamine production in tuna salad preparations. Journal of Food Protection, 78 (7), 1343-1349.

Motil, K. J. \& Scrimshaw, N. S. (1979). The role of exogenous histamine in scombroid poisoning. Toxicology Letters, 3 (4), 219-223.

Muller, G. J., Lamprecht, J. H., Barnes, J. M., De Villiers, R. V. P., Honeth, B. R. \& Hoffman, B. A. (1992). Scombroid poisoning. Case series of 10 incidents involving 22 patients. South African Medical Journal, 81 (8), 427-430.

Narayan, B., Miyashita, K. \& Hosakawa, M. (2006). Physiological effects of eicosapentaenoic acid (EPA) and docosahexaenoic acid (DHA) - A review. Food Reviews International, 22 (3), 291-307.

Official Gazette RS, (2010). Regulation on general and special conditions of hygiene of food at any stage of production, processing and transport. 72/2010.

Pacheco-Aguilar, R., Lugo-Sánchez, M. E., Villegas-Ozuna, R. E. \& Robles-Burgueño, R. (1998). Histamine quantification in Monterey sardine muscle and canned products from Northwestern Mexico. Journal of Food Composition and Analysis, 11 (2), 188-195.

Petrovic, J., Babic, J., Jaksic, S., Kartalovic, B., Ljubojevic, D. \& Cirkovic, M. (2016). Fish product-borne histamine intoxication outbreak and survey of imported fish and fish products in Serbia. Journal of Food Protection, 79 (1), 90-94.

Predy, G., Honish, L., Hohn, W. \& Jones, S. (2003). Was it something she ate? Case report and discussion of scombroid poisoning. CMAJ, 168 (5), 587-588.

Ryok Kang, C., Yun Kim, Y., In Lee, J., Don Joo, H., Wha Jung, S. \& Cho, S.-I. (2018). An outbreak of scombroid fish poisoning associated with consumption of yellowtail fish in Seoul, Korea. Journal of Korean Medical Science, 33 (37), e235.

Schulze, K., Rreusse, U. \& Tillack, J. (1979). Food poisoning by histamine after consumption of sardines in oil. Archiv fuer Lebensmittelhygiene, 30 (2), 56-59.

Silva, T. M., Sabaini, P. S., Evangelista, W. P. \& Gloria, M. B. A. (2011). Occurrence of histamine in Brazilian fresh and canned tuna. Food Control, 22 (2), 323-327.

Suyama, M. \& Yoshizawa, Y. (1973). Free amino acid composition of the skeletal muscle of migratory fish. Nippon Suisan Gakkaishi, 39 (12), 1339-1343.

Thompson, M., Ellison, S. \& Wood, R. (2002). Harmonized guidelines for single-laboratory validation of methods of analysis. Pure and Applied Chemistry, 74 (5), 835-855.

Tsai, Y.-H., Kung, H.-F., Lee, T.-M., Chen, H.-C., Chou, S.S., Wei, C.-I. \& Hwang, D.-F. (2005). Determination of histamine in canned mackerel implicated in a food borne poisoning. Food Control, 16 (7), 579-585.

Yesudhason, P., Al-Zidjali, M., Al-Zidjali, A., Al-Busaidi, M., Al-Waili, A., Al-Mazrooei, N. \& Al-Habsi, S. (2013). Histamine levels in commercially important fresh and 
processed fish of Oman with reference to international standards. Food Chemistry, 140 (4), 777-783.

Zhai, H., Yang, X., Li, L., Xia, G., Cen, J., Huang, H. \& Hao, S. (2012). Biogenic amines in commercial fish and fish products sold in southern China. Food Control, 25 (1), 303-308.
Zhang, J., Zhu, X., Xu, R., Gao, Q., Wang, D. \& Zhang, Y. (2018). Isolation and identification of histamine-producing Enterobacteriaceae from Qu fermentation starter for Chinese rice wine brewing. International Journal of Food Microbiology, 281 (1), 1-9.

Paper received: 31.05.2019.

Paper corrected: 19.06.2019.

Paper accepted: 13.06.2019. 